（66）液状化対策としてのグラベルドレーンに関する小型模型振動実験と解析

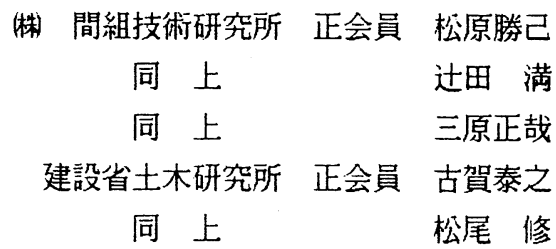

\title{
1 、まえがき
}

近年、地震時の地盤の液状化対策として、施工時に振動や騒音の少ないグラベルドレーン工法の採用が注 目を浴びている。このグラベルドレーンをある地盤上で設計する際には、ある決まったグラベルドレーンの 径に対しドレーンの施工ビッチを決定する必要があるが、この方法として、設計時に想定される最大間隙水 圧比から、Seed・B oo ker" の提案した設計図表を用いて決められることが多い。しかしながら、この図 表は、グラベルドレーン側の境界の間㗂水圧をゼロに指定する（ドレーンの透水性を無限大と考える）とい う仮定に基づいて作成されたものであり、グラベルドレーンの透水性を有限と考えるより現実に近いモデル に比べて間隙水圧を小さ沈評洒するものと考えら机る。そこで筆者らは、この点を改良するため、先に、 グラベルドレーンの透水抵抗（ウェルレジスタンス）をむ考慮した解析方法を提案した2)。本報では、その 解析方法の妥当性の検討とグラベルドレーン周辺の砂層の密度や透水性がグラベルドレーンの液状化対策と しての効果に及ぼす影響を検討する目的で、グラベルドレーン単体に対する小型模型振動実験を実施したの で、ここにその結果を報告するものである。

\section{2.グラベルドレーンに関する模型振動実験}

実験に用いた模型の概要と設置した計器の位置を図 1 に示す。図 1 亿示すように、直径 $375 \mathrm{~mm}$ 、高さ 100

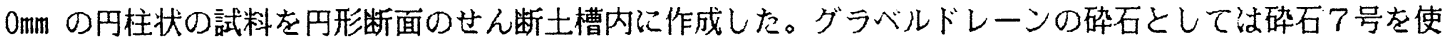
用し、砂層部には、豊浦標準砂を使用した。

実験のケースとしては、グラベルドレーンの有無、流体の種類（水およびグリセりン溶液）、秒層部の密度 により、計 8 種類を設定した。そ㣗らの実験ケースの一覧を表 1 に示す。流体としてグリセリン溶液を使用 した時は、透水係数を水の場合に対して約15分の1にするため、体積比で $60 \%$ 溶液を用いた。

砂绝部は、水あるいはグリセリン溶液中に砂を落す水中落下法により作成したが、密詰め試料を作成する

際にはタンバーを用い

て締め固めを行なった。 ドレーン部については、 内径 $10 \mathrm{~cm}$ 塩ビパィプ を設置し、その中に砕 石を投入してその後、 塩ビパイプを引きあげ \& ながら作成した。

以上の样にして作成 した試料を振動台に載 せ、強制加振を行なっ たが、入力波としては 正弦波を用い、加振時

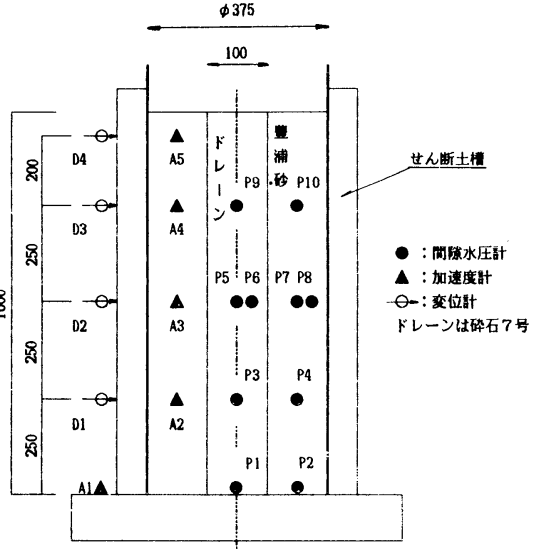

図 1 実験模型
表 1 実験ケースの一臨

\begin{tabular}{|c|c|c|c|c|c|}
\hline ケース & $\begin{array}{l}\text { トレーン } \\
\text { の有 }\end{array}$ & 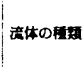 & 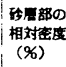 & 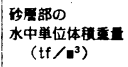 & $\begin{array}{l}\text { 台加速度 } \\
\left(\begin{array}{lll}\mathrm{g} & \mathrm{a} & 1\end{array}\right)\end{array}$ \\
\hline 1 & w & 水 & $\begin{array}{l}\text { 拮め } \\
\text { Dr=58 }\end{array}$ & 0.95 & 100 \\
\hline 2 & : & タリセリン & 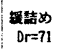 & 0.88 & 86 \\
\hline 3 & 有 & 水 & $\begin{array}{l}\text { 嘉め } \\
D r=59\end{array}$ & 0.95 & 96 \\
\hline 4 & 有 & クリセリン & $\begin{array}{l}\text { 结復め } \\
D r=65\end{array}$ & 0.87 & 90 \\
\hline 1 , & 邫 & 水 & $\begin{array}{l}\text { 密热め } \\
0 r=82\end{array}$ & 1. 00 & 90 \\
\hline $2^{\prime}$ & s & クリセリン & 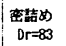 & 0.91 & 105 \\
\hline $3^{\prime}$ & 有 & 水 & 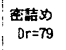 & 1. 00 & 87 \\
\hline $4^{\prime}$ & 有 & クリセリン & $\begin{array}{l}\text { 密菬め } \\
D r=84\end{array}$ & 0.91 & 83 \\
\hline
\end{tabular}



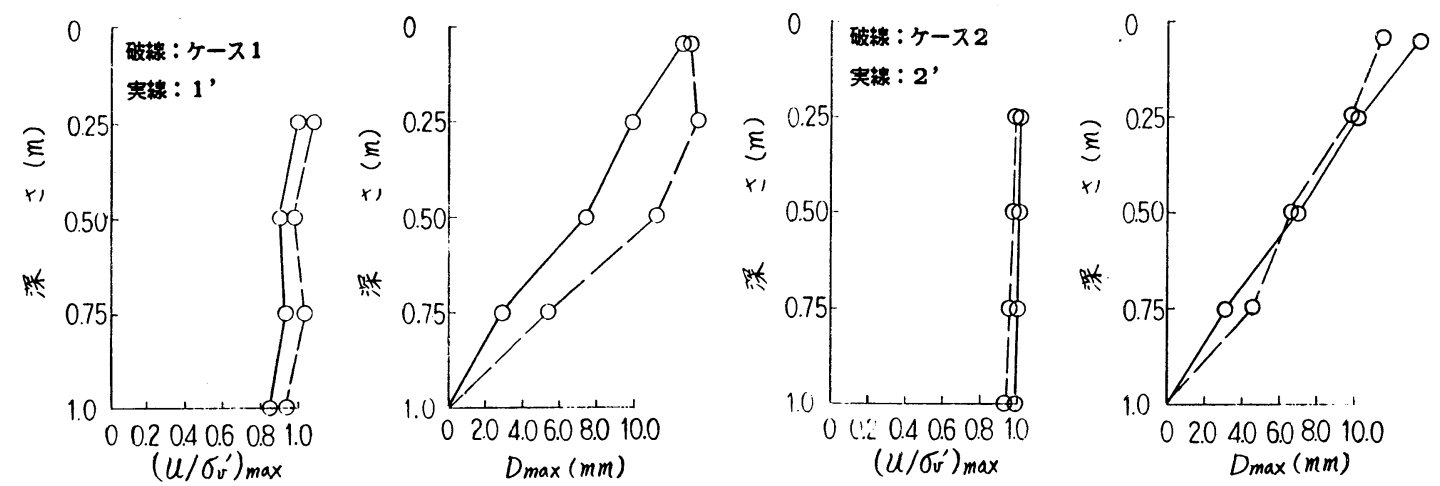

(a) ケース 1 とケース 1 '
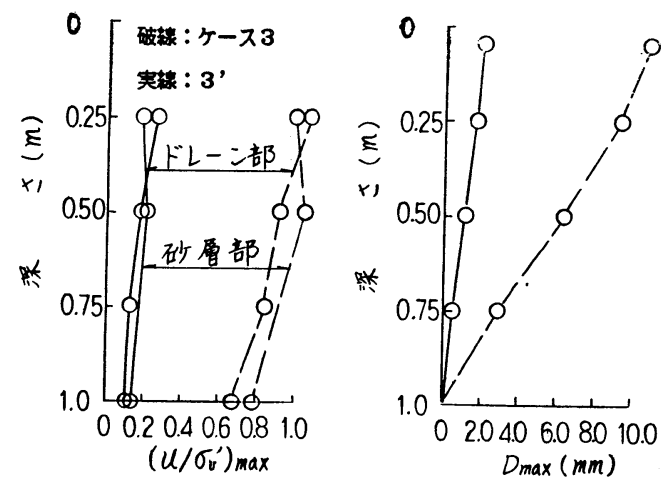

(b)

ケース 2 とケース 2 '
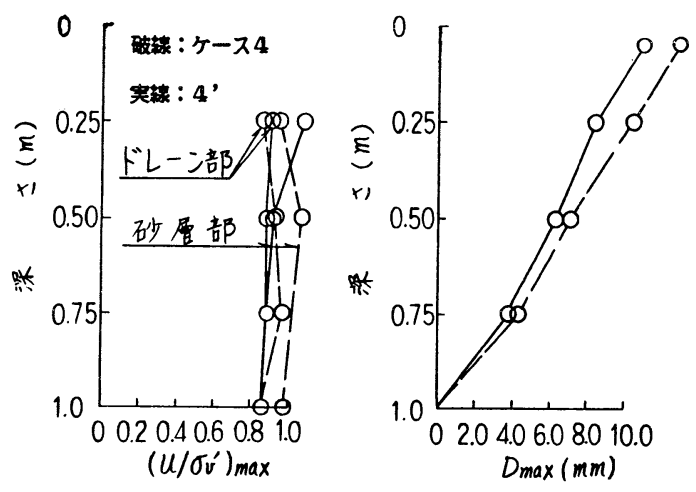

(c) ケース とケース $3^{\prime}$

(d) ケース4とケース $4^{\prime}$

図 2 間陰水圧比と変位の時刻歴最大値の深度分布

の周波数は $2 \mathrm{H} z$ また加振時間は $6 \mathrm{sec}$ であった。

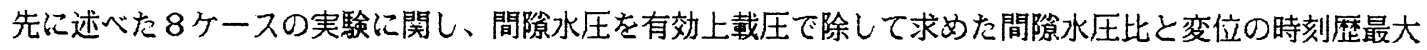
值の深度分布を図 2 に示す。図 2 の結果から言えることは以下の通りである。

(1) グラベルドレーンを設けない場合（ケース1、1'、2、2’）は、緩詰めおよび密詰め試料ともに間 隙水圧比が 0.8 以上の值を示し、砂層部全体がほぼ液状化した状熊となっている。一方、流体として水 を使用してグラベルドレーンを設计た場合には、緩詰め試料（ケース3）では試料の梁い部分で若干間 吵水圧比が減少するだけであるのに対し、密詰め試料（ケース3’）では砂層部およびドレーン部とむ 䧂水圧比が 0.2 程度の值に押えられている。これは、砂層部の密度によりグラベルドレーンの効果が顕 著に現われたりあるいは現われなかったりすることを示すものであり、砂層の液状化強度がグラベルド レーンの液状化対策としての効果に影響することを表わしていると考えられる。

(2) 流体としてグリセリン溶液を使用してグラベルドレーンを設けた場合には、緩詰めおよび密詰め試料 （ケース4、4，）とも試料全体に間鄚水圧比が 0.8 以上に達しており、グラベルドレーンの効果が余 り現われていない。(1)で述べたように、流体として水を使用した時には密な試料でグラベルドレーンの 効果が䫓著に現われたが、流体としてグリセリン溶液を使用すると密な試料でもグラベルドレーンの効 果が䫓著に現われないことがわかる。このことは、グリセリン溶液を用いた場合、ドレーンの透水係数 $\mathrm{kd}$ と砂属部の透水係数 $\mathrm{ks}$ の比 $\mathrm{kd} / \mathrm{ks}$ はある程度の大きな值を有しているとしても、砂層部の透水係数 の絶対值が水を用いた場合よりも小さくなるため、結果的にグラベルドレーンの効果が押えられたこと を意味するものと思われる。したがって、グラベルドレーンの効果は、砂绝部の透水性によっても影響 を受けると考えられる。 

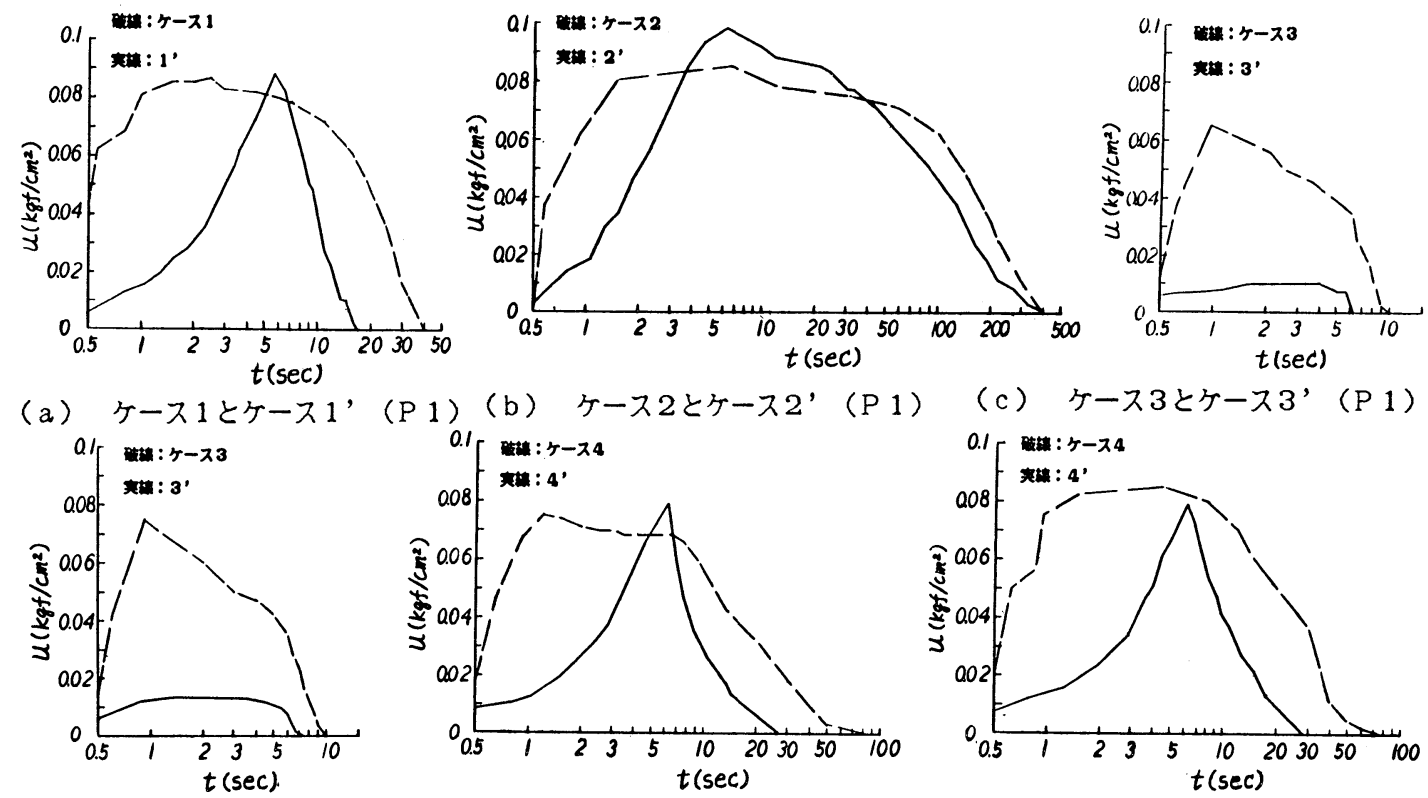

(c) ケース ととケース 3’ (P 1)

(d) ケース 3 とケース 3 '

(P 2) (e) ケース4とケース4’ (P 1)



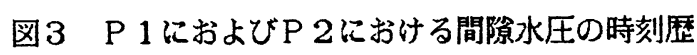

(3) 変位の時刻歴最大值の深度分布に着目すれば、ドレーンの有無、流体の種類および砂層の密度を問わ ず、試料が液状化あるいはそ机に近い状態にある時は、添ほ同程度の变位值と同様な深度分布形状を示 しているが、ドレーンの効果が顕著に現われた場合（ケース3）には变位值む小さくなっている。

図 1 に示した10台の間吵水圧計のうち 2 台のP1およじP2に着目して、間䧂水圧の時刻歴を図3に示す。図 3 の結果から言えることは、以下の通りである。

(1) ドレーンの有無および流体の種類によらず、砂層の密度の違いが間吵水圧の上昇過程に大きな影響を 及ぼしており、緩詰めの場合、加振開始後急激に間隙水圧がピークに達するのに対し、密詰め試料では 間隙水圧の上昇が緩慢になる。

(2) グラベルドレーンを設计ると、加振終了時の間吵水圧の消散がドレーンを設けない場合よりむ早い。 この傾向は、グリセリン溶液を用いた密詰め試料（ケースダ）において特に著しい。

\section{3. 実験結果の数值シミュレーション}

筆者らが先に提案した解析方法"2に基づいて、本実験結果の数值シミュレーションを行なった。数值シミ ユレーションは、前述のように実験でグラベルドレーンの効果が顕著に現われた密な試料に対して実施した。 図 1 のP1、P2、P5およじP7での間隙水圧に関して、実験結果と数值計算結果の比較を図4に示す。図4では ケース 1'ケース2'、ケース 3'およじケース4'に対する結果を示しており、実線が実験值を破線が計算 值を意味している。

計算に用いた入力データとしては、流体として水を用いたものに対しては、砂層の透水係数 $k s=1.0 \times 10^{-2}$

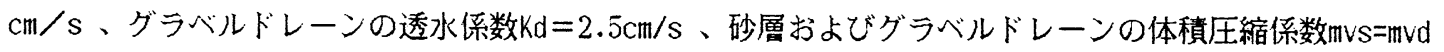
$=1.7 \times 10^{-3} \mathrm{~m}^{2} / \mathrm{tf}$ 、非排水状態で間隕水圧比が $100 \%$ に達する繰り返し数 $\mathrm{N} \&=8$ 回、入力の等価繰り返 し回数 $\mathrm{Neq}=12$ 回および地震動有効継続時間 $t d=6.0 \mathrm{sec}$ 用いた。また、流体としてグリセりン溶液を 用いたものに対しては、KsおよじKdを水の場合の15分の 1 亿設定した。ここに、mvsおよびN eの值は、流 体として水を用いたドレーンのない場合（ケース1）について、間吵水圧の時刻歴に関し、実験結果と計算 結果とが適合するように決定し、KsおよびKdの值は、別途実施した透水試験の結果を参考にして決めた。 


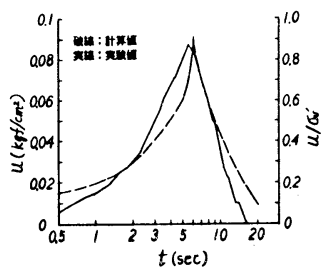

(a) ケース 1', P 1

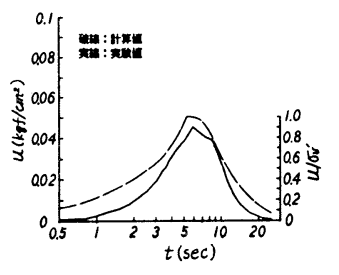

(b) ケース 1’, P 5

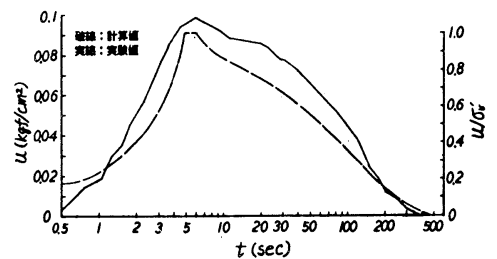

(c) ケース $2^{\prime}, \mathrm{P} 1$
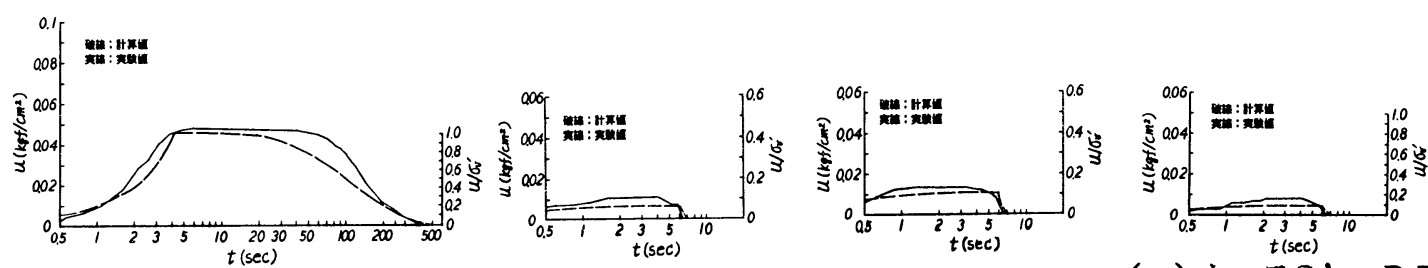

(d) ケース 2', P 5

(e) ケース 3', P 1

(f) ケース ’’,

P 2 (g) ケース $3^{\prime}$, P 5
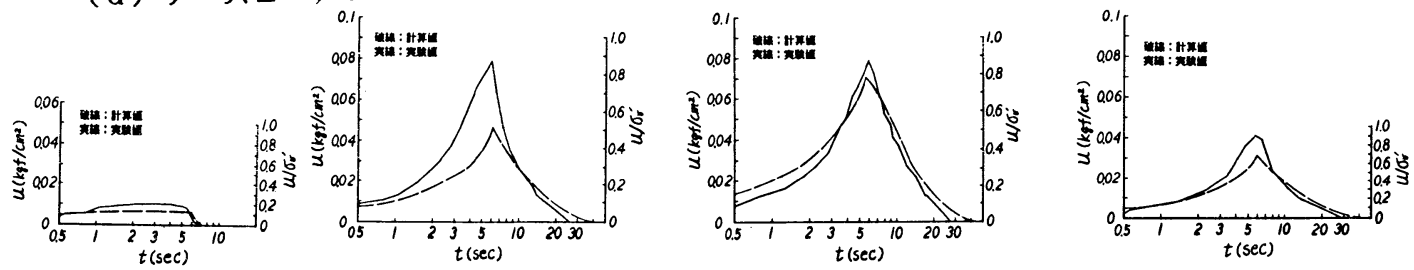

(h) ケース 3’, P 7

(i ) ケース $4^{\prime}, \mathrm{P}_{1}$

(j) ケース 4’, P 2

(k) ケース4’, P 5

図4実験結果と数値計算結果の比較

図4において、ケース 2’ケース3’およじケース4’の実験值と計算值の 比較結果によれば、グリセりン溶液を用いたドレーンのある場合のドレーン内 （（i ）、(k））で計算値が実験値をやや下回る結果となっているが、他の ケースでは、実験値と計算值が比較的良い照合を示しており、本解析方法の適 合性がうかがえる。

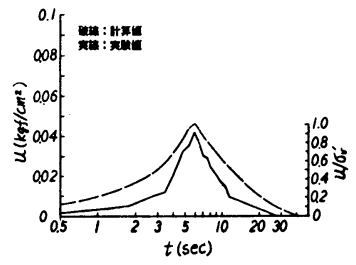

(1) ケース $4^{\prime}, \mathrm{P} 7$

\section{4.まとめ}

グラベルドレーン単体に体する小型模型振動実験とその解析により、以下のことが明らかとなった。

(1) グラベルドレーンの液状化対策としての効果は、砂層部の密度いいかえれば砂啗部の液状化強度の影 響と砂層部の透水性の影響を受ける。これは、筆者らが提案した解析手法で用いている無次元パラメー 夕では、 $N$ eq $/ \mathrm{N}$ \&と $\mathrm{T} d=(t d k s) /\left(a^{2} \gamma_{w} \mathrm{mvs}\right)$ ( $a$ はドレーン半径) の評価が重要である ことを示唆するものと考えられる。

(2) 先に提案したドレーンのウェルレジスタンスを考慮した解析方法、すなわち地震時の過剩間隕水圧の 発生を考慮した压密方程式を用いる方法を使用することにより、グラベルドレーン周辺地盤の間陸水圧 上昇、消散過程を工学的に十分な精度で追跡可能である。

\section{5.あとがき}

最後に、本報は、建設省耐震地盤改良工法に関する共同研究の一部をまとめたものであり、関係各位の御 指導に感謝するとともに、本実験に協力のあった青山機工㑣の藤崎新一氏に感謝の意を表します。

(参考文献) 1) Seed, H. B. , Booker, J.R. , A S C E, Vol. 103, G T 7, 1977 2)古賀泰之, 谷口栄一, 辻田满, 三原正哉, 松原勝己, 土質工学研究発表会, 1987 